\title{
Work-Related Fatigue Risk-Determining Factors in Traditional Metal Casting Industry in Klaten
}

\author{
Maria Paskanita Widjanarti*, Apriliana Rachmawati \\ Diploma of Occupational Health and Safety \\ Universitas Sebelas Maret \\ Surakarta, Indonesia \\ *mpaskanita@gmail.com, aprilianarahmawati05@gmail.com
}

\begin{abstract}
Fatigue is one of risk factors in an occupational accident and could result in injuries or health problems. This research was aimed at analysing the determinant fatigue risk factors in traditional metal casting industry. The study was a quantitative observational analytic research with cross sectional design conducted in Traditional Metal Casting Industry in Klaten. There were 39 respondents selected as samples through a purposive sampling method. Spearman correlation and SPSS program were used for data analysis. The result showed that there were correlation between body mass index and workrelated fatigue $(p=0.033, r=-0.343)$ and hydration status and work-related fatigue $(\mathrm{p}=0.003, \mathrm{r}=0.473)$. Body mass index and hydration status affected the work-related fatigue up to $30.5 \%$. There were no correlation between age $(p=0.118, r=0.254)$, years of services $(p=0.062, r=0.301)$, and workload $(p=0.357, r=-0.152)$ to work fatigue.
\end{abstract}

Keywords: body mass index, hydration status, work related fatigue

\section{INTRODUCTION}

Indonesia is still unable to produce production machinery for the metal casting industry, according to the Chairperson of the Indonesian Metal Casting Association (HAPLI). Orders are still on a limited scale to meet the economic scale. This limitation is also experienced in producing equipment with high precision. The metal casting industry in Indonesia still needs to be spurred and developed to achieve high [1]. The traditional metal casting industry in Klaten also contributes to the metal casting industry in producing components or plates for equipment machinery. The metal casting industry in Klaten still prioritizes manual power and has not used production machines. Work productivity will depend on the work capacity of workers. Workers who experience work exhaustion will experience a decrease in efficiency and productivity will decrease. Factors that cause work exhaustion need to be handled so that workers can work productively and efficiently.

Metal Casting crew working in hot and humid environment. Based on Indonesian Minister of Manpower Regulation No. 5 of 2018, metal casting was categorized moderate workload based on metabolite rate $(140-240 \mathrm{~W} / \mathrm{m} 2)$ [2]. Hot work environment, humidity and moderate workload condition tend to caused work-related fatigue. Construction worker where worked at hot climate and humid and heavy physical workload were experienced fatigue before and after work [3]. Working in high ambient temperature may lead into injury risk, injury was increasing $1 \%$ for each $1{ }^{\circ} \mathrm{C}$ increase in daily minimum temperature [4]. Body heat production could increase 1 $\mathrm{kcal} / \mathrm{min}$ to $20 \mathrm{kcal} / \mathrm{min}$ while conducted physical work at hot environment. Theoretically, heat production will increase core temperature $1{ }^{\circ} \mathrm{C}$ every 5 to 7 minute. When cooling progress of metabolic heat production via sweating, irradiation, conduction and convection failed, the core temperature will above $38{ }^{\circ} \mathrm{C}$. It made human body experience excessive dehydration, heat exhaustion or heat stroke, chemical tolerance decreased and fatigue [5].

Fatigue can be influenced by the intensity of work duration, work environment, circadian rhythm, health conditions and nutrition. The disadvantages can also be influenced by age, gender, work period and nutritional status as the work capacity of the worker affects work fatigue Error! Reference source not found. Duration of sleep, psychological distress, perception of health and higher exposure to physical work factor were associated with acute fatigue level [7]. Workrelated fatigue of Australian industry were influenced by duration of sleep, work hours, and workload Error! Reference source not found.. Work-related fatigue among medical personnel in Taiwan were influenced by age, job description, amount of coffee consumption and health condition [9]. Fatigue on construction workers were influence by working time and water consumption [3]. Fatigue risk scores were differed by specialty but not by gender [10]

Work-related fatigue research commonly observed on nurses, physician, railway worker, construction worker and mine workers. There was limited observation on work-related fatigue on metal casting worker. This research observed workrelated fatigue risk factor determinant: age of respondent, years of service, work environment temperature as part of workload calculation based on Indonesian regulation physical work factor, hydration status as water consumption profile, and body mass index to see worker nutrition.

\section{Subject AND Method}

The research used the analytic observational designs with cross sectional study. This study was held at ANJ Co Ltd, Klaten. The samples were 39 workers from totally 67 production workers at ANJ Co Ltd, Klaten. All workers are 
male workers with duration of work 8 hours per day. The age of respondent selected between 25-60 years old, years of services more than 5 year, good health self-report status, and voluntary respondent.

The measurement of Body mass index used weight scales and microtoise staturmeter. The worker workload was measured by using pulse check, and hydration status checked using Uryxxon Relax from Solo Laboratory and Quest Temp Heat Stress Monitor to check the work thermal. Industrial Fatigue Research Committee (IFRC) Questionnaire was used to check fatigue self -report. The data were analysed using Spearman's correlation test.

\section{RESULTS}

ANJ Co Ltd was one of the many traditional metal casting in Ceper Klaten. Workers who are respondents are aged 25-60 years. There was no correlation between age and fatigue at ANJ Co Ltd as shown in Table 1.

TABLE I. AgE OF RESPONDEN AND FATIGUE

\begin{tabular}{|c|c|c|c|c|c|c|}
\hline \multirow[t]{2}{*}{$A G E$} & \multicolumn{3}{|c|}{ Fatigue } & \multirow[t]{2}{*}{$\mathbf{N}$} & \multirow{2}{*}{$\begin{array}{c}\mathbf{P} \\
\text { Value }\end{array}$} & \multirow[t]{2}{*}{$\mathbf{r}$} \\
\hline & Low & Moderate & High & & & \\
\hline $\begin{array}{ll}\leq 35 & \text { years } \\
\text { old } & \\
\end{array}$ & 2 & 5 & 4 & $\begin{array}{l}11 \\
(28 \%)\end{array}$ & 0,118 & 0.254 \\
\hline $\begin{array}{l}\text { "> } 35 \text { years } \\
\text { old }\end{array}$ & 0 & 11 & 17 & $\begin{array}{l}28 \\
(72 \%)\end{array}$ & & \\
\hline
\end{tabular}

Most of workers, around $82 \%$ had been worked for more than 10 years as shown in table Tabel 2. There was no correlation between years of service and fatigue at ANJ Co Ltd

TABLE II. YEARS OF SERVICES AND FATIGUE

\begin{tabular}{|l|l|l|l|l|l|c|}
\hline & \multicolumn{3}{|c|}{ Fatigue } & N & $\begin{array}{c}\text { P } \\
\text { Value }\end{array}$ & \multirow{2}{*}{ R } \\
\cline { 2 - 5 } & Low & Moderate & High & & 0.301 \\
\hline$\leq 10$ years & 2 & 3 & 2 & $7(18 \%)$ & 0,062 & $0.32 \% n$ \\
\hline " $>10$ years & 0 & 13 & 19 & $32(82 \%)$ & & \\
\hline
\end{tabular}

Worked Thermal at ANJ Co. Ltd is $30.88-33-760{ }^{\circ} \mathrm{C}$. Work thermal has exceeded the Threshold Limit Value (TLV) of the Minister of Manpower Regulation No. 5 of 2018 [2], which states that metal casting work is included in the category of moderate to heavy workload, with $75 \%-100 \%$ working time division having the permissible hot work climate is $28.0^{\circ} \mathrm{C}$. Although the work climate exceeds the threshold, the workload of the worker ANJ Co Ltd, still in light and medium workload category based on the measurement of the pulse of the workers which shown in table 3. There was no correlation between the workload and fatigue

TABLE III. WORK LOAD

\begin{tabular}{|l|l|l|l|l|l|c|}
\hline \multirow{3}{*}{ Work Load } & \multicolumn{3}{|c|}{ Fatigue } & \multirow{N}{*}{$\begin{array}{c}\text { P } \\
\text { Value }\end{array}$} & $\mathbf{R}$ \\
\cline { 2 - 4 } & Low & Moderate & High & & 0,357 & 0,152 \\
\hline Light & 2 & 1 & 3 & & & \\
\hline Moderate & 0 & 15 & 18 & & & \\
\hline
\end{tabular}

The body mass index (BMI) of ANJ Co Ltd worker in the range of normal and overweight. There was significant correlation between body mass index and fatigue of the worker as shown in table 4.

TABLE IV. BODY MASS INDEX AND FATIGUE

\begin{tabular}{|c|c|c|c|c|c|c|}
\hline \multirow{2}{*}{$\begin{array}{l}\text { Body Mass } \\
\text { Index }\end{array}$} & \multicolumn{3}{|c|}{ Fatigue } & \multirow[t]{2}{*}{$\mathbf{N}$} & \multirow{2}{*}{$\begin{array}{c}\mathbf{P} \\
\text { Value }\end{array}$} & \multirow[t]{2}{*}{$\mathbf{R}$} \\
\hline & Low & Moderate & High & & & \\
\hline Normal & 2 & 10 & 19 & $\begin{array}{l}31 \\
(79 \%) \\
\end{array}$ & 0,033 & $\begin{array}{l}-0, \\
343 \\
\end{array}$ \\
\hline Overweight & 0 & 6 & 2 & $\begin{array}{l}8 \\
21 \%)\end{array}$ & & \\
\hline
\end{tabular}

Working in high thermal condition required the worker to consume fluids. At least $250 \mathrm{ml}$ water every 20 minutes or 6 litters for 8 hours worked Error! Reference source not found.. Hydration status of respondent has been hydrated for $54 \%$, and moderately-dehydrated to dehydrated for $46 \%$ as shown in table 5 . There was correlation between hydration status and fatigue of ANJ Co Ltd workers.

TABLE V. Hyration Status AND Fatigue

\begin{tabular}{|l|l|l|l|l|l|c|}
\hline \multirow{2}{*}{$\begin{array}{l}\text { Hydration } \\
\text { Status }\end{array}$} & \multicolumn{3}{|c|}{ Fatigue } & \multicolumn{1}{c|}{ N } & $\begin{array}{c}\text { P } \\
\text { Value }\end{array}$ & R \\
\cline { 2 - 5 } \cline { 3 - 4 } & Low & Moderate & High & & & \\
\hline Dehydrated & 0 & 0 & 2 & $2(5 \%)$ & 0,003 & 0,473 \\
\hline $\begin{array}{l}\text { Moderately- } \\
\text { Dehydrated }\end{array}$ & 0 & 3 & 13 & $\begin{array}{l}16 \\
(41 \%)\end{array}$ & & \\
\hline $\begin{array}{l}\text { Middly } \\
\text { hydrated }\end{array}$ & 2 & 10 & 2 & $\begin{array}{l}14 \\
(36 \%)\end{array}$ & & \\
\hline $\begin{array}{l}\text { Well } \\
\text { hydrated }\end{array}$ & 0 & 3 & 4 & $7(18 \%)$ & & \\
\hline
\end{tabular}

\section{DISCUSSION}

There was no correlation between age and fatigue of the workers ANJ Co Ltd, $p=0.062$ and $r=0.301$. Age of the worker has a large effect on muscle strength where the maximum age of muscle strength is at the age of 25-35 years and has decreased by $15-25 \%$ at the age of 50-60 years [11]. ANJ Co Ltd workers ages less than 35 years already have subjective feeling of moderate and high fatigue for $28 \%$. This also happened to workers who are aged 35-60 years who experience moderate and high fatigue as much as $72 \%$ so that age does not affect worker fatigue. A person's work period will affect the process of experience of workers in doing work with a better position and not resulted in fatigue Error! Reference source not found.. The workload of metal casting work according to the Minister of Manpower Regulation number 5 of 2018 was categorized as moderate and heavy workload, but the workers at ANJ Co Ltd were experienced workload in the light and medium categories when measured by pulse per minute (between 75-125 pulses / minutes) Error! Reference source not found.. It resulted there was no correlation between the workload and fatigue at ANJ Co Ltd workers.

Workers who have Overweight Body Mass Index experience work fatigue. The value of a high body mass index or overweight is one of the predictors of the occurrence of fatigue derived from health habits in the general population in 
the study with 7900 respondents in Europe [14]. The body mass index also has an influence on the level of worker fatigue such as the level of mild fatigue or severe fatigue Error! Reference source not found.. Obesity contributes to subjective physical fatigue beyond the level explained by depression mood and level inflammatory markers interleukin 6 (IL 6) and soluble form of intercellular adhesion molecule 1 (sICAM) and Body mass index were significantly related to general fatigue subscale as Multidimensional Fatigue Symptom Inventory (MFSI) [16].

Hydration status has significant correlation to worker fatigue at ANJ Co Ltd. The average workers at ANJ Co Ltd consumed as much as 4 litters during the last 24 hours. It less than the suggested regulation, which workers in the hot workplace were expected to drink $0.75 \mathrm{~L}$ every 1 hour or 6 litters for 8 working hours [17]. The hydration status of ANJ Co Ltd workers as many as $46 \%$ experienced moderately dehydrated and dehydrated. Cardiovascular conditions, thermoregulation and metabolic and central nerves will experience changes in function and will reduce performance in high dehydration conditions. Performance decreased will occur more in work activities in a hot environment than in cold environment [18]. Changes in the body function will resulted lower attention, lower psychomotor and memory ability directly because brain capability was reduced in conditions of mild dehydration and moderate dehydration [19]. Dehydration conditions disrupt cognitive abilities (short-term memory) and subjective feelings of fatigue [20]. Workers should be given a liquid or drink solution containing $50 \mathrm{~g}-1$ glucose and $1.34 \mathrm{gl}$ - $1 \mathrm{NaCl}$ in a volume of water that corresponds to $100 \%$ of their body weight or in $100 \mathrm{ml}$ of water to prevent a decrease in work after 3.5 or 4 hours of dehydration or during work breaks [20]. Management system of work-related fatigue could be develop by Employer, such as identified critical work situation and specific source of fatigue by selected specific operational measures, psychomotor characteristic as based of work tasks selection, selected employee to specific task groups, recommended work task to employee to minimize particular fatigue, and standard work procedure to reduced fatigue [21]. Physical activity has reciprocal relation to work related fatigue, increasing physical activity will decrease in work-related factor. Stable level of work-related fatigue achieved by employee who have norm physical activity [22].

\section{CONCLUSIONS}

There was significant correlation between body mass index and hydration status on subjective work-related-fatigue in ANJ Co Ltd workers. ANJ Co Ltd need to provide liquid or drink solution containing $50 \mathrm{~g}-1$ glucose and $1.34 \mathrm{gl}-1 \mathrm{NaCl}$ in a volume of water that corresponds to $100 \%$ of their body weight or in $100 \mathrm{ml}$ of water to maintains performance and need improvement in eating habits and health to control the body mass index.

\section{ACKNOWLEDGMENT}

The authors would like to express our appreciation to respondent at ANJ Co Ltd for their cooperation in this research.

\section{REFERENCES}

[1] Ministry of Industry and Trade, [Online] Retrieved from: http://www.kemenperin.go.id/artikel/10635/Jepang-Relokasi-PabrikPengecoran-Logam-ke-Indonesia, 2017.

[2] Indonesian Ministry of Man Power, Indonesian Ministry of Man Power Regulation No 5, "Workplace safety health and environment indonesia," pp. 258, Jakarta: Department of Manpower, 2018.

[3] A.N. Zahra, L.M. Kuriawidjaja, "Construction worker fatigue conditions at pt. $x$ construction contractor apartment development in the 2017 work year," International Conference of Occupational Health and Safety, pp. 46-58, 2018.

[4] J.A. McInnes, M. Akram, E.M. MacFarlane, T. Keegel, M.R. Sim, P. Smith, "Association between high ambient temperature and acute workrelated injury: a case-crossover analysis using workers' compensation claims data," Journal of Work, Environment \& Health, vol. 43(1), pp. 86-94, 2017.

[5] E. Marchetti, P. Capone, D. Freda, "Climate change impact on microclimate of work environment related to occupational health and productivity," Annali, A science journal for public health, vol. 52(3), pp. 338-342, 2016.

[6] D.L. Setyowati, Z. Shaluhiyah, B.Widjasena, "Factors caused fatigue among furniture workers," Jurnal Kesehatan Masyarakat Nasional, vol. 8(8), 2014.

[7] L. Laberge, M. Perrron, "Risk factors for work-related fatigue in students with school-year employment," Journal of Adolescent Health, vol. 48(3), pp. 289-294, 2011.

[8] J. Dorrian, D. Dawson, "Workhours, workload, sleep, and fatigue in australian rail industry employees," Applied Ergonomics. vol. 42(2), pp. 202-209, 2011.

[9] J.Ho, S. Lyu, "Work-related fatigue among medical personnel in taiwan," Journal of the Formosan Medical Asociation, vol. 112(10), pp. 608-615, 2013.

[10] P. Gander, C. Briar, A. Garden, H. Purnell, A. Woodward, "A genderbased analysis of work patterns, fatigue, and work/life balance among physicians in postgraduate training," Academic Medicine, vol. 85(9), pp. 1526-1536, 2010.

[11] Tarwaka, "Industrial Ergonomic," Surakarta: Uniba Press, 2015.

[12] K.H.E. Kroemer, E. Grandjean, "Fitting the task to the human: a textbook of occupational ergonomics," 5th ed, Routledge: Taylor \& Francis, 1997.

[13] Christensen, "Encyclopaedia of occupational health and safety," ILO, Geneva, 1991.

[14] D.M. Rose, A. Seidler, M. Nübling, U. Latza, E. Brähler, E.M. Klein, J. Wiltink, M. Michal, S. Nickels, P.S. Wild, J. König, M. Claus, S. Letzel and M.E. Beute, "Associations of fatigue to work-related stress, mental and physical health in an employed community sample 1," BMC Psychiatry, vol. 17(167), 2017.

[15] H. Kagamiyama, R.Yano, "Relationship between subjective fatigue, physical activity, and sleep indices in nurses working 16-hour night shifts in a rotating two-shift system," Journal of Rural Medicine, vol. 13(1), pp. 26-32, 2018.

[16] W.Lim, S.Hong, R.Nelesen, "The association of obesity, cytokine levels, and depressive symptoms with diverse measures of fatigue in healthy subjects,” Jama Internal Medicine, vol. 165(8), pp. 910-915, 2005.

[17] R.W.Kenefick, M.N. Sawka, "Hydration at the work site," Journal of the American College Nutrition, vol. 26, pp. 597-603S, 2007.

[18] B. Murray, "Review hydration and physical performance," Journal of the American College of Nutrition, vol. 26, pp. 542S-548S, 2007.

[19] A. Adan, "Cognitive performance and dehydration," Journal of the American College of Nutrition, vol. 31(2), pp. 71-78, 2012.

[20] C. Cian, P. ABarraud, B. Melin, C. Raphel, "Effects of fluid ingestion on cognitive function after heat stress or exercise-induced dehydration," 


\section{PRESS}

International Journal of Psychophysiology, vol. 42(3), pp. 243-251, 2001.

[21] M. Butlweski, L. Pacholski, "Fatigue of miners as a key factor in the work safety system. procedia manufacturing," vol. 3, pp. 4732-4739, 2015.
[22] J.D de Vries, B.J.C. Claessens, M.L.M. van hooff, S.A.E. Geurts, S.N.J van den Bossche, M.A.J. Kompier, "Disentangling longitudinal relations between physical activity, work-related fatigue, and task demand," International Archives of Occupational and Environmental Health, vol. 89(1), pp. 89-101, 2016. 